\title{
MODIFICATION OF DA'WA THROUGH INTERNALIZATION OF DA'WATAINMENT IN PRANK VIDEO CONTENT ON YOUTUBE
}

\author{
Vyki Mazaya ${ }^{1}$, Rizza Olivia Novitasari ${ }^{2}$ \\ 1,2State Islamic Institute of Pekalongan \\ 1vyki.mazaya@iainpekalongan.ac.id, 2rizzaolivia88@gmail.com
}

\begin{abstract}
Da'wa efforts in the era of disruption with the presence of online-based new media provide a space of expression for anyone to convey da'wa through unlimited creativity with various innovations. Da'wa is not always delivered seriously in a formal atmosphere but da'wa can be packaged in a relaxed manner, can be enjoyed in a relaxed and even entertaining way. Collaboration between da'wa and entertainment known as da'watainment is expected to be able to attract the millennial generation who are the largest users of YouTube media so that da'wa messages can be packaged through communication media that are close to the world of the millennial generation with concepts that are trending among millennials, one of which is prank. Prank content had gone viral after drawing a lot of criticism and protests because it contained useless substances and actually caused harm. Creative ideas are needed to modify useless content into useful content that is still interesting and entertaining. This study describes qualitatively descriptive from the data obtained from virtual observations on prank content and prank shalawat on Gus Aldi's YouTube channel which inspires millennial $D a^{\prime} i-D a^{\prime} i$ in conveying da'wa messages through YouTube. In this content there is a varied structure in broadcasting shalawat as well as other messages of Islamic teachings which are also conveyed in a humorous, relaxed, and entertaining way.
\end{abstract}

Keywords: Modification, Da'watainment, YouTube, Da'wa Media, Prank

Abstrak: Upaya dakwah di era disrupsi dengan hadirnya media baru berbasis online memberikan ruang berekspresi bagi siapa saja untuk menyampaikan dakwah melalui kreativitas tanpa batas dengan berbagai inovasi. Dakwah tidak selalu disampaikan secara serius dalam suasana formal tetapi dakwah dapat dikemas secara santai, dapat dinikmati dengan santai bahkan menghibur. Kolaborasi antara dakwah dan hiburan yang dikenal dengan istilah da'watainment diharapkan mampu menarik minat generasi milenial yang merupakan pengguna media YouTube terbesar sehingga pesan dakwah dapat dikemas melalui media komunikasi yang dekat dengan dunia maya. generasi milenial dengan konsep yang sedang ngetren di kalangan milenial, salah satunya adalah prank. Konten prank menjadi viral setelah menuai banyak kritik dan protes karena mengandung zat yang tidak berguna dan justru merugikan. Dibutuhkan ide-ide kreatif untuk mengubah konten yang tidak berguna menjadi konten bermanfaat yang tetap menarik dan menghibur. Penelitian ini mendeskripsikan secara deskriptif kualitatif dari data yang diperoleh dari observasi virtual pada konten prank dan shalawat prank di channel YouTube Gus Aldi yang menginspirasi Da'i-Da'i milenial dalam menyampaikan pesan dakwah melalui YouTube. Dalam konten ini terdapat struktur yang bervariasi dalam penyiaran shalawat serta pesanpesan ajaran Islam lainnya yang juga disampaikan dengan cara yang lucu, santai, dan menghibur.

Kata kunci: Modifikasi, Da'watainment, YouTube, Media Dakwah, Prank 


\section{A. Introduction}

Da'wa is not only a religious activity, but also $d a^{\prime} w a$ is an activity that is focused on the substance of Islamic teachings. ${ }^{1}$ As long as the path taken does not conflict with the sources of Islamic teachings, namely the Qur'an and Hadith, da'wa can be carried out in various forms and creativity. $D a^{\prime} i$ innovation is needed so that da'wa activities always develop dynamically giving new nuances for the achievement of the success of da'wa.

Based on the survey of APJII (Association of Indonesian Internet Service Providers) the results of the 2019-2020 internet user penetration were 73.7\%, namely 196.71 million people out of a total population of 266.91 million Indonesians. ${ }^{2}$ According to the research agency marketing. We Are Social and social media management application company Hootsuite, YouTube is in the top position in media usage compared to other platforms. ${ }^{3}$ The results of the study stated that $86 \%$ of YouTube users not only use YouTube as a means of seeking entertainment but also as a medium for learning.4

The use of media as an intermediary for delivering da'wa so that mad'ū as an object of da'wa are easier to understand the message conveyed, more interesting and mad'u are not bored in receiving da'wa messages as research results state that YouTube is an effort to optimize celebrity ustadz and Da'i YouTuber use communication media as a medium of da'wa. ${ }^{5}$ The use of media is an important consideration because media users are active and have the power to choose and use the media they want.

Creativity is the key to content creation. One alternative is to modify useless content into useful content. Among the popular video content formats are pranks. In prank content there is usually a target that is used as a target for activities that are identical to pranks, jokes, humor whose main purpose is to entertain.

Viewers. However, prank content often contains something that is less useful and even has an evil nature. ${ }^{6}$ As research by Yahya, et al. that the stretching of da'wa on YouTube is seen as positive that supports da'wa, it can be formulated into two strategies, namely content creating and collaboration. ${ }^{7}$ Gus Aldi is a YouTuber or content creator who modifies prank content with materials containing Islamic values and amar ma'ruf nahi munkar which is packaged in da'watainment on YouTube.

\section{B. Theoretical Review}

Research on da'wa and YouTube has attracted the attention of researchers to continue to conduct research from various perspectives and research focuses. There are several studies that have relevance to this research as follows:

First, Samsinar in his study on da'wa Innovation Through Multimedia. In the journal Al-Din:

\footnotetext{
${ }^{1}$ A. Wibawa "Fenomena Dakwah di Media Sosial Youtube". Jurnal Rasi, 1. (2019).pp.1-19.

${ }^{2}$ APJII. Laporan Survey Internet. (2020)

3 B.Clintenn. Kompas.com. (Y. Pratomo, Editor) Retrieved 10 9, 2021, from https://tekno.kompas.com/read/2021/02/24/17020027/pengguna-medsos-di-indonesia-habiskan-25-jamper-bulan-untuk-nonton-youtube. (2021)

${ }^{4}$ Ibid.

${ }^{5}$ F. Arifin. "Mubalig Youtube dan Komodifikasi Konten Dakwah". Al-Balagh:Jurnal Dakwah dan Komunikasi, 4, (2019):108.

${ }^{6}$ S. Rantona. Persepsi Netizen Media Sosial Instagram Dalam Konten Prank Ferdian Paleka. Jurnal Komunikasi, Masyarakat dan Keamanan, 2,(2020).pp.70.

7 Y.U. Yahya. "Da'wah di Youtube: Upaya Representasi Nilai Islam oleh Para Content-Creator". Anida (Aktualisasi Nuansa Ilmu Dakwah), 20, (2020).pp. 4.
} 
Journal of Religious and Social Da'wa, 4(1). ${ }^{8}$ This research focuses on the need for da'wa innovation in various elements of da'wa such as materials, methods, preachers, media, and other elements as a form of response to advances in the field of science and technology to obtain optimal results, both multimedia da'wa, and da'wa through community empowerment. So that the preacher is required to master the media in the delivery of da'wa. ${ }^{9}$

Second, Arifin in his study, Mubalig YouTube and Commodification of Da'wa Content. In the journal Al-Balagh: Journal of Da'wa and Communication, 4(1), 91-120.10 This study focuses on the transformation of dai into celebrity preachers who enliven YouTube and explores the perception of the Islamic community in Indonesia if the social media channels of celebrity ustadz are commodified. The strategy of a preacher to package da'wa content so that it can be sold in the market, while at the same time generating interest in generating profits in certain contexts. The method used in this study is specifically directed towards virtual and visual observations (virtual ethnography) on some da'wa content displayed on YouTube by several Indonesian ustadz. YouTube is interpreted as a form of utilizing social media which in the end is able to bring in income based on clicks, likes, views, and the number of followers (subscribers) so that there is a change and transfer of the function of media messages as a form of commodity (commodification). ${ }^{11}$

Third, Wibawa,The Phenomenon of Da'wa on YouTube Social Media, in Rasi Journal, 1(1), 119.12 This paper describes the phenomena and models of new da'wa in the digital era. Da'wa becomes public consumption wherever and whenever anyone can access da'wa with different goals. The method used in this study is a qualitative method, with a phenomenological approach that describes the variety and form of da'wa that occurs in cyberspace, especially social media. ${ }^{13}$

Fourth, Yahya, Y. K., Untung, S. H., \& Fajari, I. A, Da'wa on YouTube: Efforts to Represent Islamic Values by Content-Creators. ${ }^{14}$ In the journal Anida (Actualization of the Nuances of Da'wa), 20(1), 122. This article describes two movements in cyberspace, namely the movement to create content (content-creating) and collaboration with well-known content-creators (collaboration) to expand networks and gain more viewers. With these two movements, researchers will see the impact generated by the number of viewers in the videos. ${ }^{15}$

Fifth, Hamdan, H., \& Mahmuddin, M, YouTube as a Da'wa Media. Palita: Journal of Social Religion Research, 6(1), 63-80.16 This research is library research related to the da'wa program via YouTube which has very promising prospects, both in terms of effectiveness and from the economy. There are several models of da'wa on YouTube, namely; serial lecture video model; short video lecture model; lecture snippet video model; music/song model; short story video model; direct flow model; and community videos. ${ }^{17}$

Some of the studies above discuss da'wa and YouTube, but in this study, they focus more on modifying prank accounts by internalizing da'watainment through virtual observations on the structure of prank shalawat video content on Gus Aldi's YouTube channel. To describe the modification of the da'wa content, the underlying theory is needed, as follows:

\footnotetext{
${ }^{8}$ S. Samsinar. "Inovasi Dakwah Melalui Multimedia”. Al-Din: Jurnal Dakwahdan Sosial Keagamaan, 4. (2019)

${ }^{9}$ Ibid.

${ }^{10}$ F. Arifin. "Mubalig Youtube dan Komodifikasi Konten Dakwah".

11 Ibid.

12 A. Wibawa "Fenomena Dakwah di Media Sosial Youtube".

13 Ibid.

14 Y.U. Yahya. "Da'wah di Youtube: Upaya Representasi Nilai Islam oleh Para Content-Creator".

${ }^{15}$ A. Wibawa "Fenomena Dakwah di Media Sosial Youtube".

${ }^{16}$ H. Hamdan. "Youtube sebagai Media Dakwah". Palita: Journal of SocialReligion Research, 6, (2021):63-80.

17 Ibid.
} 


\section{Modification of $\mathrm{Da}^{\prime}$ wa}

Modification is the activity of making changes. According to the definition that said by Masdar Helmy, da'wa can be understood as the activity of conveying the message of amr ma'ruf nahi munkar (calling for virtue and preventing evil) originating from the teachings of Islam to achieve happiness in the world and in the hereafter. ${ }^{18}$ Modification of da'wa can be said as an activity of quoting, imitating, or imitating by making changes or giving a different touch from existing da'wa products or content. Da'wa innovations are changes made in preaching. In principle, Islamic da'wa can be carried out flexibly. ${ }^{19}$ This innovation can be done from all elements of da'wa such as materials, methods, preachers, media, and other elements. $D a^{\prime} i$ are required to have knowledge and skills in using media in order to keep up with the times. ${ }^{20}$

New media with its characteristics have been able to encourage the growth of new religious practices that are only found in virtual space. Cyberspace forms an interactive space in cyberspace. ${ }^{21}$ As mentioned by Bungin, "the world of interaction is now divided into the real world and the virtual world.22 The results of the study indicate that in the practice of online da'wa, there is a modification process to the practice that occurs in conventional da'wa in real space. Hamdan, et al said that there are several models of da'wa on YouTube, namely; serial lecture video model; short video lecture model; lecture snippet video model; music/song model; short story video model; direct flow model; and community videos. ${ }^{23}$ This model still uses conventional da'wa methods, it's just that the delivery is through the online media YouTube so that the message is conveyed in a formal atmosphere that is thick with religious nuances. This model can still be developed into more relaxed entertainment content, but the substance presented invites goodness and prevents evil. One of the attractiveness

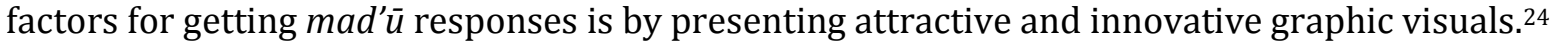

In da'wa activities, there are five elements that must move dynamically because da'wa is a dynamist towards happiness in the world and in the hereafter. ${ }^{25}$ The elements of da'wa are described as follows:

First, Da'i or da'wa actors are people who carry out da'wa. Qualifications in Islamic scholarship are the main thing as an attraction, but changing times and styles are also aspects that need attention because the appearance of the preacher is part of the appearance that will make the first impression. The current style of $D a^{\prime} i$ is diverse, not always dressed with Islamic religious symbols such as wearing koko, sarong, cap, carrying prayer beads, etc. The $D a^{\prime} i^{\prime} s$ style of dress also changes according to developing trends and adapts to the target of his da'wa.

Second, the message of da'wa must always be based on the Qur'an and Hadith which are the main guidelines for Muslims. The problems of the people are increasingly emerging contemporary problems that never existed during the time of the Prophet Muhammad so that the role of the Da'i to answer contemporary problems becomes an alternative solution for the people.

Third, da'wa media or means of da'wa are tools used to disseminate da'wa messages. The media has the advantage of disseminating information more efficiently. Mad'ū makes it easier to access information with the presence of new media.

\footnotetext{
18Moh. Ali Aziz. Ilmu Dakwah. Jakarta: Kencana. Bungin. Sosiologi Komunikasi.(Jakarta: Kencana. 2008).

19 N. Alhidayatillah. "Dakwah Dinamis Di Era Modern (Pendekatan Manajemen Dakwah)". An-Nida', 41 (2018):269.

20 S. Samsinar. "Inovasi Dakwah Melalui Multimedia".

${ }^{21}$ A.S. Muhtadi, A. S. Komunikasi Dakwah. (Bandung: Simbiosa Rekatama Media. 2017)

22 Burhan Bungin. Sosiologi Komunikasi : Teori, Paradigma, dan Diskurs Teknologi Komunikasi Masyarakat.

(Jakarta: Kencana Prenada Group, 2008)

${ }^{23}$ H. Hamdan. "Youtube sebagai Media Dakwah".

${ }^{24}$ A. Wibawa "Fenomena Dakwah di Media Sosial Youtube".

${ }^{25}$ A. Karni. Dakwah Islam dan Dinamika Masyarakat. (Padang: The MagdafFondation, 2005)
} 
Fourth, the method of da'wa. The method is a way to achieve the success of da'wa. The method has been formulated in Q.S. An Nahl: 125 which mentions three methods of preaching (calling to the way of God), namely: bil hikmah, bil mau'idhah hasanah, mujlah billati hiya ahsan. In this case, bil hikmah is one method of preaching wisely to understand the needs and conditions of the honey, including the trends that are being favored by honey. The verse presents the context of an adaptive da'wa innovation that adapts to its $\operatorname{mad}^{\prime}{ }^{26}$ In the Uses and Gratification theory of communication, media users are considered to be active in choosing media according to their needs. ${ }^{27}$ Likewise, da'wa media needs to be adjusted to the needs of the mad'ü so that it is right on target.

Fifth, the da'wa effect is the expected impact after mad'ū receives the $d a^{\prime} w a$ message. These changes can be in the stages of cognitive, affective, and behavioral changes.

\section{Internalization of da'watainment}

Internalization is defined as merging or unifying attitudes, behaviors and opinions (Shiddieqy, 1984). Waluyo defines internalization as the process of planting awareness. ${ }^{28}$ In the context of $d a^{\prime} w a$, internalization is the process of planting $d a^{\prime} w a$ into other aspects that have the potential to support the success of da'wa. The collaboration between $d a^{\prime} w a$ and entertainment is called da'watainment.

In the internalization process, an exemplary approach can be used. This modeling strategy can be categorized into internal modeling and external modeling. Internal exemplary is the example of the closest people such as family, relatives, friends, neighbors. External examples come from figures who should be imitated, such as kyai, inspirational figures, motivators, expert sources, both local and international figures. ${ }^{29}$

In new media era, external examples can be obtained from media influencers such as YouTubers, celebrities, artists on television and other media who have an influence on their fans both in terms of fashion, lifestyle, perspective, etc. become a trend setter for his fans. Therefore, the position of the preacher as an influencer on YouTube needs to build a positive trend for YouTube users but still look attractive.

\section{Prank video content on YouTube}

YouTube has become one of the favorite media among the people. Many content creators use YouTube as a place to express their ideas and creativity in the content they present. Content that is currently in great demand by content creators is prank. Prank contains a video of a prankster pranking someone. Pranks, jokes in the form of activities that are not in accordance with logic or reasoning. ${ }^{30}$

The prank content become a concern because it is considered a moral crisis and is contrary to the Qur'an and Hadith. One of the prank contents that went viral and drew a lot of criticism was the prank content created by Ferdian Paleka who gave boxes filled with trash to Waria in order to get lots of views and likes which were considered beyond the limits of humanity. The perpetrator of the

26 V.N. Noekent. "Inovasi Dakwah Perguruan Tinggi (Studi Naratif pada Universitas Negeri Semarang)". Komunike, 12(2), (2020):202.

27 P. Rianto, P. "Media Baru, Visi Khalayak Aktif dan Urgensi Literasi Media”. JurnalKomunikasi Ikatan Sarjana Komunikasi Indonesia, 1(2), (2016):96.

${ }^{28}$ Armiah. "Internalisasi Nilai-Nilai Keagamaan Lewat Media”. Alhadharah, (2014)

${ }^{29}$ Ibid.

30 D. Cecariyani. "Analisis Strategi Kreatif Dan Tujuan Konten YouTube (Studi KasuKonten Prank Yudist Ardhana”. Prologia, 2, (2019):495. 
content creator was ultimately jailed and the content was removed from the account. ${ }^{31}$

Seeing useless content, can be used as a valuable lesson and as a motivation for content creators to pay more attention to the quality of content and the value of benefits from the content created, not just pursuing financial gain.

\section{Methods}

This type of research is field research using a qualitative descriptive approach. Data obtained from direct observation virtual on Gus Aldi's YouTube channel, as well as documentation from literature relevant to this research. The observed videos are prank sholawat video content. The researcher observed the prank shalawat video on Gus Aldi's YouTube channel and then identified the structure in the content of the prank shalawat video.

\section{Results and Discussion}

\section{Substance of Prank Video Content on YouTube}

YouTube provides the flexibility for its users to actualize their creativity in a virtual space in various videos with concepts that are displayed both for educational, informational, business, and entertainment purposes. This freedom provides an opportunity for YouTube users not only to enjoy existing videos but also to actively produce video content. Content creators compete to make video content watched by many viewers, one of which is the motivation to get rewards from YouTube based on monetization. YouTube video content creators known as YouTubers, are now not only seen as an entertainment activity, but YouTubers are now starting to become one of the promising activities because they are able to generate fantastic income coffers if managed professionally and consistently. Therefore, many YouTubers are competing to create content and even ignore the value of the benefits in their video content solely to earn income. One of them is prank video content. Although media content like this does not contain any benefits, the fact is that there are many viewers and even one of the prank videos contents has gone viral because it has received a lot of criticism for ignoring human moral and social values.

Prank video content is one of the video contents that is known to contain elements of ignorance, deceit, which is deliberately done to the people who are the target. In prank content, it often makes the target the aggrieved party and can even trigger someone's emotions. Some forms of pranks include:

a. Providing information that seems true to the target with the aim of being believed, but when the target has believed it turns out that the information provided is not true with the aim of being a joke.

b. The content creator in this prank content tries to attract viewers by displaying the target's spontaneous reactions and expressions to the stimulus in the form of incorrect information. These expressions and reactions often bring up something unexpected that occurs naturally and often triggers emotions and disputes because the information provided is intentionally intended to provoke a situation into conflict. Content creators want to give satisfaction to their viewers as a form of entertainment or entertainment but harm the target's trust.

c. Giving goods to the target but the contents are unexpected, usually the item does not match the

31 F. Isnawan. "Konten Prank Sebagai Krisis Moral Remaja di Era MilenialDalam Pan-dangan Psikologi Hukum dan Hukum Islam". Jurnal Surya Kencana Satu: Dinamika Masalah Hukum dan Keadilan, 12(1), (2021):2. 
recipient's expectations which is used as a joke. YouTubers try to show a surprised expression from the recipient in order to arouse a laugh response from the viewer. This can lead to disappointment from the target and even trigger conflict with the recipient. It's like giving boxes of trash to people who need help. Such prank content lacks social sensitivity and lacks empathy for other people who are having a hard time.

d. Setting a trap so that the target enters the setting, the trap can be a hole, water spray, etc. The target is shocked by the traps in his path and is at risk of causing dangerous consequences or harming others.

In general, the substance of pranks is contrary to Islamic values in Surah Almaidah verse 2 which teaches to help each other in goodness and piety and prohibits helping each other in sinning and enmity. In addition, it also contradicts the values of honesty because in Prank content contains elements of deception. Although the purpose is for jokes and entertainment, lying is not justified in Islam because it can hurt someone's belief. Whereas honesty and trustworthiness are one of the role models of the Prophet Muhammad SAW as in the hadith of the Prophet Muhammad SAW that the Prophet Muhammad was sent to the world to perfect morals. Noble morality is the main thing that is important and becomes a character that every Muslim must have.

\section{Modification of Da'wa Through Internalization of Da'watainment in Prank Video Content on YouTube}

Da'wa is an activity to change something for the better. Various efforts have been made to innovate that can be done through modification of propaganda packaging, including by modifying prank content, which mostly contains jokes that are not useful, into prank content with substances containing Islamic teachings. One of the YouTubers who until now can be called a millennial preacher or YouTuber $D a^{\prime} i$ is Gus Aldi's YouTube channel.

The observations of researchers on a YouTube channel named Gus Aldi, information was obtained that this YouTube channel was started on July 27, 2015. With the number of videos that have been uploaded and 2.83 million subscribers, until the last time accessed on October 10, 2021 and has been reached 358,324,445 views. In the description of this channel, it does mention that this channel contains the Prophet's prayer, religious pop songs and Islamic parodies that contain da'wa values. So it is clear that Gus Aldi's YouTube channel is intended for da'wa purposes.

This YouTube channel has prank sholawat video content. In this sholawat prank content, it is inseparable from the entertainment element that contains jokes but what needs to be underlined is jokes that do not harm others. Watching entertainment is one way to refresh the mind and relax the body. In addition, this prank modification also features the act of humming shalawat from Gus Aldi as a form of entertainment that combines da'wa and entertainment known as da'watainment. From the observations of researchers, Gus Aldi consistently tries to introduce and broadcast shalawat to a wide audience through his content on YouTube.

The concept of Gus Aldi's Da'watainment video content can be said as a new concept that maintains the positive sides of the idea of a prank video production that emphasizes the reaction and spontaneous expression of the prank targets, then replaces other parts that have an element of harm with the substance of the message of amr ma'ruf. Nahi munkar which is packaged in a relaxed and humorous way. The model, Islamic da'wa is delivered in a relaxed manner, there is no element of coercion, and mad'ū do not feel that they are being preached, they feel comforted.

From this content, researchers have identified the structure of prank shalawat content on YouTube that can be used as propaganda media, as follows:

a. The opening section contains a snippet.

The first part of the opening is the most important part because the first part is the display that will be taken into account by the viewer to decide whether to watch or not, interesting or not 
by looking at the first few seconds as a sample. If the start is good, the viewers will continue watching for the next duration. If the initial impression is not interesting, viewers are less likely to continue or even switch to other interesting content.

b. Delivering short tausyiyah about good messages.

From the results of this study, there are messages related to knowledge about the teachings of Islam, such as about qurban, about blessings, about prayer, etc. These da'wa messages are delivered in an indefinite duration

too long so that the feel of entertainment remains dominant in prank video content. The duration of tausiyyah that is too long can be at risk of saturation. Judging from the casual way of dressing, the contemporary language, it can be concluded that this kind of da'wa model is suitable for millennial audiences. The millennial generation tends to like something new, likes things that are packaged in a relaxed manner, which is in accordance with the trends that are developing at that time.

c. Always start with a prayer before driving.

One of the characteristics of this sholawat prank video content is that it often uses settings in the car, because the preachers in this content are capturing their targets by becoming online drivers. The preacher as the driver conditioned the prank target to sit in the front seat to make it easier to communicate during the trip. In addition, the placement of the target position is also an important consideration in producing a proportional video composition and lighting related to the camera layout so that it is pleasing to the eye. Before the journey begins, the preacher always invites the target ( $m a d^{\prime} \bar{u}$ ) to pray together following the reading of the prayer recited by the preacher. The video can be said that the da'wa that is carried out not only uses the method of da'wa orally but also through da'wa bil hal in the form of an example, inviting prayer together. For the target, this $d a$ 'wa is effective because mad'ū immediately practice prayer together. For viewers, prayers before the trip are also a reminder when they want to travel.

d. Prank shalawat as an online driver.

In the process of delivering the target/customer takes time to get to the destination location. This time was used by the YouTuber preacher to carry out his prank action which began by singing a song deliberately pretending to be false to get the target's amused expression. However, when changing to chanting prayers, the target who had underestimated showed an expression of amazement and enjoyed the chanting of the shalawat echoed in a melodious voice. In this session, the preacher tried to highlight the prayer as if to emphasize that the prayer is also comfortable to listen to. The response from the target is also positive and enjoys chanting shalawat.

e. Good looking talent.

One of the characteristics of the prank sholawat video on Gus Aldi's YouTube channel is that the average target is beautiful women. In this sholawat prank, the $D a^{\prime} i$ who plays the role of an online driver cannot choose who will be delivered, but when he gets a good-looking female customer, he can be used as a target to be uploaded as da'wa content. Determination of this talent or target, is seen as one strategy to attract viewers.

f. Jokes

The modifications content of shalawat prank are also inserted with the acting of online drivers on the phone, in their conversations containing jokes that are often illogical but instead invite laughter. Not infrequently issuing seduction sentences but still polite that makes the target flatter and blush. The $D a^{\prime} i$ YouTuber who acts as an online driver often calls himself Sultan Juki who claims to be a very rich person, his conversations seem to be imagining beyond logic but instead become part of entertaining for the target with various expressions in response to jokes that thrown. 
g. Asking the customer for permission to upload to YouTube.

Taking hidden cameras or candid cameras that are not realized by the target may document something that is considered private by the target. As a form of ethics in respecting the privacy of others, at the end of the video, the YouTuber preacher gives permission to the target to upload the video to YouTube. The uploaded videos have received permission from the target concerned.

h. Free delivery service fees.

At the end of the trip, the YouTuber preacher as an online driver often provides free delivery services to the target because he is willing to be a talent in prank shalawat video content. There is a relationship of mutual help in goodness.

From the identification of several structures that exist in the modification of da'wa through internalization of $d a$ 'watainment in prank video content on YouTube, it can be concluded that the content in the form of pranks can be used as a medium of $d a^{\prime} w a$ as long as it does not conflict with the teachings of Islam. Islamic values are instilled through the example practiced by the preacher who is carried out consistently in his video content, especially such as praying before driving and chanting prayers during the trip. Prank video content not only provides entertainment but also the loyal viewers unconsciously, every time watching it, they have made good habits, namely listening to prayers as exemplified by the preacher in his YouTube content. From the results of this study, preachers can develop creativity in formulating creative ideas in the form of $d a^{\prime} w a$ content that does not seem textual.

\section{E. Conclusion}

The results of this study, researchers can conclude as follows that the substance of prank video content on YouTube is generally not appropriate because it contains something that is not useful only to entertain but ignores the aspect that must be maintained, namely honesty. Prank videos are generally just looking for satisfaction by doing something that has been set and planned an ignorant activity, which can harm others, even cause disappointment and loss of trust or cause harm to others. This is contrary to the struggle of the Prophet Muhammad SAW in perfecting the morals of his people and becoming an honest and trustworthy people.

Modification of pranks on YouTube can be done by internalizing da'wa messages including shalawat which is then packaged in a relaxed manner, the appearance of the Da'i according to mad' $\bar{u}$ from the millennial circle so that da'wa can be delivered in a fun way because it is packaged in the form of entertainment. The exemplary strategy appears in the prank content of shalawat by providing an example of reading a prayer every time you drive and chanting the Prophet's prayer during the trip which is a da'wa bil hal. In one prank sholawat video content, there are several structures so that the video has variations to avoid audience saturation. In principle, the preacher maintains something that is good and replaces the bad elements into good ones according to the guidance of the Qur'an and Hadith.

It is hoped that the results of this study can make a positive contribution to da'wa research, especially related to the development of da'wa media in the era of disruption that requires innovation in accordance with the needs of $m a d^{\prime} \bar{u}$. The researcher realizes that there are many short comings in writing this article, so we expect constructive criticism through future research.

\section{Reference}

Alhidayatillah, N. "Dakwah Dinamis Di Era Modern (Pendekatan ManajemenDakwah)”. An-Nida', 41 (2018):269.

APJII. Laporan Survey Internet. (2020)

e-ISSN: $2686-6048$

w-3 ${ }^{\text {rd }}$ ICONDAC - October 19-20, 2021 
Arifin, F. "Mubalig YouTube dan Komodifikasi Konten Dakwah". Al-Balagh:Jurnal Dakwah dan Komunikasi, 4, (2019):108.

Armiah. "Internalisasi Nilai-Nilai Keagamaan Lewat Media”. Alhadharah, (2014)

Aziz, M. A. Ilmu Dakwah. Jakarta: Kencana. Bungin. Sosiologi Komunikasi. Jakarta: Kencana. (2008).

Bungin, Burhan. SosiologiKomunikasi: Teori, Paradigma, dan Diskurs Teknologi Komunikasi Masyarakat. Jakarta : Kencana Prenada Group. 2008.

Cecariyani, d. "Analisis Strategi Kreatif Dan Tujuan Konten YouTube (StudiKasuKonten Prank Yudist Ardhana”. Prologia, 2, (2019):495.

Clintenn, B. Kompas.com. (Y. Pratomo, Editor) Retrieved 10 9, 2021, from https://tekno.kompas.com/read/2021/02/24/17020027/pengguna-medsos-di-indonesiahabiskan-25-jam-per-bulan-untuk-nonton-YouTube. (2021)

Hamdan, H. "YouTube sebagai Media Dakwah". Palita: Journal of Social Religion Research, 6, (2021):63-80.

Isnawan, F. "Konten Prank Sebagai Krisis Moral Remaja di Era MilenialDalam Pan-dangan Psikologi Hukum dan Hukum Islam”. Jurnal Surya Kencana Satu: Dinamika Masalah Hukum dan Keadilan, 12(1), (2021):2.

Karni, A. Dakwah Islam dan Dinamika Masyarakat. Padang: The Minangkabau Fondation. (2005)

Muhtadi, A. S. Komunikasi Dakwah. Bandung: Simbiosa Rekatama Media. (2017)

Noekent, V. N. "Inovasi Dakwah Perguruan Tinggi (Studi Naratif pada Universitas Negeri Semarang)". Komunike, 12(2), (2020):202.

Rantona, S. "Persepsi Netizen Media Sosial Instagram Dalam Konten Prank Ferdian Paleka". Jurnal Komunikasi, Masyarakat dan Keamanan, 2,(2020):70.

Rianto, P. "Media Baru, Visi Khalayak Aktif dan Urgensi Literasi Media". JurnalKomunikasi Ikatan Sarjana Komunikasi Indonesia, 1(2), (2016):96.

Samsinar, S. "Inovasi Dakwah Melalui Multimedia". Al-Din: Jurnal Dakwahdan Sosial Keagamaan, 4. (2019)

Shiddieqy, H. A. Pedoman Zakat. Jakarta: PT. Bulan Bintang, (1984)

Wibawa, A. “Fenomena Dakwah di Media Sosial YouTube”. Jurnal Rasi, 1. (2019):1-19.

Yahya, Y. U. "Da'wah di YouTube: Upaya Representasi Nilai Islam oleh Para Content-Creator". Anida (Aktualisasi Nuansa Ilmu Dakwah), 20, (2020) : 4. 